\title{
BINGKAI BERITA KEMANUSIAAN DALAM HARIAN KOMPAS DAN REPUBLIKA TERHADAP PENGUNGSI ROHINGNYA (ANALISIS FRAMING PADA BERITA KOMPAS DAN REPUBLIKA EDISI 6 - 11 SEPTEMBER 2017 MENGENAI PENGUNGSI ROHINGNYA)
}

\author{
Fadila Prihandini ${ }^{1}$, Fajar Junaedi ${ }^{2}$ \\ 'Program Studi Ilmu Komunikasi Universitas Muhammadiyah Yogyakarta \\ ${ }^{2}$ Program Studi Ilmu Komunikasi Universitas Muhammadiyah Yogyakarta \\ Email: fadila.prihandini.2014@fisipol.umy.ac.id, fajarjun@umy.ac.id
}

\begin{abstract}
ABSTRAK
Konflik berkepanjangan yang terjadi antara militer Myanmar dengan pengungsi Rohingnya kembali terulang. Pada tahun 2017, terjadinya krisis kemanusiaan Rohingnya dipicu oleh serangan kelompok militan Arakan Rohingnya Salvation Army (ARSA) yang menyerang pos penjagaan militer Myanmar pada 25 Agustus 2017. Adanya konflik ini mengakibatkan warga sipil menjadi korban. Akibatnya, gelombang eksodus pengungsi Rohingnya terus berdatangan dari Rakhine State menuju Banglades. Pemberitaan mengenai krisis kemanusiaan Rohingnya menjadi kontroversi, pihak pemerintah Myanmar menyatakan adanya disinformasi, sementara jumlah pengungsi Rohingnya terus bertambah meninggalkan Myanmar. Ketidakberdayaan pengungsi Rohingnya dikemas secara berbeda oleh dua media, bingkai pemberitaan mengenai krisis kemanusiaan Rohingnya disajikan Kompas sebagai masalah kemanusiaan internasional Kompas banyak menyampaikan kinerja pemerintah dalam membantu menangani krisis kemanusiaan Rohingnya. Berbeda dengan Republika yang melihat permasalahan kemanusiaan Rohingnya sebagai masalah umat Islam. Republika begitu kuat dalam memperjuangkan keselamatan minoritas Muslim Rohingnya, keberpihakan Republika sudah jelas pada sejumlah berita yang ditampilkan. Sedanagkan Kompas terlihat berimbang dengan tidak terlalu memperlihatkan keberpihakannya kepada pengungsi Rohingnya. Namun, di balik itu semua, kedua media dengan latar belakang yang berbeda ini tidak bisa dilepaskan dari kepentingan organisasi. Melalui paradigma konstruksionisme, diketahui bahwa realitas dalam berita tidaklah tunggal melainkan jamak. Selain itu, adanya level organisasi dan level ekstramedia memiliki imbas yang signifikan dalam sebuah organisasi media yang mengikuti selera pasar, berita mengenai kemanusiaan memiliki nilai universal yang menjual.
\end{abstract}

Kata Kunci : Konstruktivisme, Bingkai Pemberitaan, Framing, Pengungsi Rohingnya

\section{A. PENDAHULUAN}

Tragedi kekerasan yang dialami oleh warga Rohingya kembali terulang, konflik yang melibatkan sisi kemanusiaan ini sesungguhnya adalah konflik yang berkepanjangan. Gelombang pengungsian pertama dalam skala besar terjadi pada tahun 2012, kemudian terulang lagi pada beberapa tahun berikutnya, dan gelombang pengungsi Rohingnya dengan skala besar kembali terjadi di tahun 2017 yang melibatkan konflik antara militer Myanmar dengan etnis Rohingnya.

Bermula pada 25 Agustus 2017, saat sejumlah militan muslim penuntut hak kewarganegaraan Myanmar yang biasa dikenal dengan Arakan Rohingnya Salvation Army (ARSA), tertangkap melakukan serangan pada beberapa pospos penjagaan milik militer Myanmar. Tindakan dari beberapa gerilyawan ini kemudian mengakibatkan serangan 
balasan dari tentara Myanmar dalam skala besar, diantaranya adalah pemerkosaan, pembunuhan, penganiayaan, bahkan pembakaran tempat tinggal di sejumlah desa yang mereka tinggali. Akibat peristiwa ini, gelombang pengungsi Rohingnya ke Bangladesh terus meningkat. Ratusan ribu Muslim Rohingnya bertolak dari wilayah Rakhine State menuju Bangladesh, salah satu negara yang berbatasan dengan Myanmar. Mereka berjalan berharihari untuk dapat sampai ke kamp-kamp pengungisan di wilayah Cox's Bazar, daerah di Bangladesh yang kini dipenuhi dengan pengungsi Rohingnya. Pengungsian ini melibatkan banyak anak kecil, perempuan dan juga orangtua. Kebanyakan diantara mereka mengalami trauma, ketakutan dan kelelahan, baik fisik maupun mental. Beberapa diantara mereka juga tiba dengan luka tembak dan anggota tubuh yang tidak lengkap akibat ledakan ranjau darat yang mereka temui di perbatasan MyanmarBangladesh (Kompas dan Republika, edisi 6 sampai 11 September 2017).

Adanya gelombang eksodus pengungsi Rohingnya ini kemudian banyak menyita perhatian dunia internasional, berita mengenai krisis kemanusiaan Rohingnya ini termasuk dalam berita internasional. Berita internasional memiliki jangkauan wilayah yang luas dan pengaruh yang besar. Cakupannya dapat meliputi beberapa negara, bahkan seluruh dunia. Berita-berita yang dimaksudkan disini adalah berita yang tidak bersumber lokal ataupun nasional yang memiliki sifat penting mengenai negara-negara lain dan juga organisasi internasional (Flournoy, 1989: 31).

Kemunculan berita tentunya tidak bisa dilepaskan dari media yang memiliki peran begitu penting di era sekarang, sebab semua pemberitaan baik dan buruk dikemas oleh media. Krisis kemanusiaan Rohingnya dalam berita ini menekankan pada unsur kemanusiaan yang dapat menggiring perhatian masyarakat Indonesia. Menjadikan peristiwa yang banyak diikuti, walaupun tidak terjadi di dalam negeri. Sebab hak asasi manusia itu bersifat universal, permasalahannya tidaklah sama dengan seluruh kawasan di dunia, pemahamannya juga bergantung dari sudut pandang negara-negara ataupun kelompok-kelompok non pemerintah (Harahap, 2000 : 84). Adanya kedekatan secara geografis dan demografis IndonesiaMyanmar tentu dapat menjadikan kedua negara ini memiliki kesamaan dalam melihat nilai universal yang menjadi sifat dari hak asasi manusia.

Dari sejumlah media di Indonesia yang memberitakan berita mengenai krisis kemanusiaan Rohingnya, sejumlah media cetak menempatkan berita kemanusiaan Rohingnya di sampul utama. Di antara media cetak tersebut adalah surat kabar harian Kompas dan Republika.

Tulisan ini bertujuan untuk melihat bingkai berita kemanusiaan yang dibentuk antara Kompas dan Republika dalam menampilkan berita mengenai pengungsi Rohingnya. Kedua surat kabar tersebut memiliki perbedaan dalam corak agama, latar masa pemerintahan saat dibentuk,sampai visi misi yang begitu kental menjadi pengkajian dalam pandangan konstruksionis milik Kompas dan Republika ini menjadi menarik.

Pandangan konstruksionis melihat bahwa berita yang disajikan bukan merupakan mirror of reality, karena berita tersebut merupakan konstruksi awak media dari realitas yang terjadi. Melibatkan ideologi, pandangan, dan nilai-nilai dari wartawan atau media yang bersangkutan. Realitas yang sama bisa jadi menghasilkan berita yang berbeda, sebab sudut pandang yang berbeda (Curran (1991) dalam Eriyanto, 2002 : 29).

Penelitian mengenai bingkai pemberitaan pengungsi Rohingnya ini menggunakan model analisis framing Zhongdang Pan dan Gerald M. Kosciki. Framing sendiri menurut Pan dan Kosciki adalah strategi konstruksi dan memproses berita. Perangkat kognisi yang digunakan dalam mengkode informasi, menafsirkan peristiwa, dan dihubungkan dalam rutinitas dan konvensi pembentukan berita (Narendra, 2008). 
Sumber data untuk tulisan ini berasal dari berita mengenai pengungsi Rohignya yang diterbitkan oleh surat kabar harian Kompas dan Republika. Periode publikasi yang diambil adalah edisi 7, 6, dan 11 untuk harian Kompas, sedangkan edisi 7, 8 dan 10 September 2017 untuk harian Republika. Pengambilan sejumlah periode tersebut adalah berita yang terbit pasca serangan yang dilakukan oleh kelompok militan Rohingnya pada militer Myanmar, hingga akhirnya mengakibatkan krisis kemanusiaan Rohingnya meletus. Pengambilan berita dalam edisi tersebut bukan tanpa alasan, sebab pemberitaan tersebut dilakukan secara kontinyu dengan headline berita yang menggambarkan respon masyrakat Indonesia, diantaranya datang dari pihak pemerintah, beberapa lembaga kemanusiaan dan juga lembaga keagamaan Selain itu juga respon masyarakat Indonesia mengenai pengungsi Rohingnya diwarnai dengan beberapa aksi solidaritas yang digelar di berbagai lokasi di tanah air.

Berita mengenai pengungsi Rohingnya dari kedua harian tersebut kemudian dianalisis dengan perangkat framing milik Zhongdang Pan dan Gerald M. Kosciki yang terdiri dari (1) struktur sintaksis (2) struktur skrip (3) struktur tematik (4) struktur retoris. Selanjutnya faktor-faktor yang memengaruhi bingkai berita Kompas dan Republika mengenai pengungsi Rohingnya dianalisis menggunakan faktorfaktor yang memengaruhi proses produksi berita (Shoemaker \& Reese 1996: 63-252) diantarnya adalah; (1) level ideologi (2 level individu (3) level organisasi (4) level ekstramedia.

Bingkai pemberitaan atau framing kerap ditemui dalam penelitian yang membahas mengenai berita dan jurnalisme. Melalui penelusuran penulis terhadap peneltian mengenai pengungsi Rohingnya ataupun penelitian yang menggunakan metode analisis framing terhadap dua surat kabar harian Kompas dan Republika, terdapat tiga penelitian yang relevan dengan pengungsi Rohingnya ataupun yang mengarah pada framing terhadap harian Kompas dan Republika.
Penelitian pertama merujuk pada penelitian terdahulu yang pernah dilakukan oleh Gonda Yumitro(2017:60-75). Penelitian ini berjudul Respon Dunia Internasional terhadap Tragedi Kemanusiaan Rohingnya (penelitian ini menggunakan teknik pengumpulan data melalui studi pustaka yang berasal dari berbagai sumber. Menerapkan penelitian deskriptif yang menggunakan pendekatan kualitatif. Penelitian ini fokus pada respon masyarakat yang cukup masif, baik di level bilateral, regional maupun internasional dalam menyikapi isu Rohingnya. Menggunakan konsep Responsibility to Protect yang mengerucut pada politik internasional, penelitian ini mendorong semua pihak untuk melakukan hal yang konkret, yaitu peduli dengan nilai-nilai moralitas dan kemanusiaan dalam menyelesaikan akar persoalan Rohingnya.

Penelitian kedua merujuk pada penelitian oleh Dewa Gede Sudika Mangku (2013, 60-75). Penelitian ini berjudul Kasus Pelanggaran HAM Etnis Rohingnya: Dalam Perspektif ASEAN yang dimuat dalam Jurnal Media Komunikasi FIS (2013) yang menjelaskan mengenai pelanggaranpelanggaran hak asasi manusia yang dilakukan pemerintah Myanmar kepada etnis Rohingya. Penelitian ini melihat dari kacamata hukum dengan penyajian data secara deskriptif dan dianalisis secara kualitatif.

Penelitian Ketiga, penelitian yang dilakukan oleh Mubarok dan Made Dwi Adnjani (2012 : 25-41). Penelitian ini diberi judul Konstruksi Pemberitaan Media tentang Negara Islam Indonesia (Analisis Framing Republika dan Kompas). Penelitian ini layak digunakan sebagai acuan penelitian terdahulu karena memiliki objek penelitian yang sama yaitu harian Kompas dan Republika. Selain itu dalam penelitian ini banyak diungkapkan mengenai bagaimana peristiwa yang dikonstruksi media massa menjadi lebih bermakna untuk menunjukkan sikap, keberpihakan/vested interest yang ada di balik pemberitaan media.

Analisis bingkai pemberitaan ini akan mengambil 3 berita dari Kompas dan 3 
berita dari Republika. Berita sendiri Menurut Wahyudi, berita/news memiliki definisi sebagai laporan tentang suatu peristiwa/ event. Selain itu juga dapat dikatakan sebagai pendapat yang mengandung nilai penting, baru atau aktual, menarik untuk khalayak dan juga dipublikasikan secara periodik (Wahyudi, 1987).

Dilihat secara umum, dalam pengaplikasiannya pers dan konstitusi yang berlaku pada suatu Bangsa tidak bisa dipisahkan. Hubungan antara karya jurnalistik dengan konstitusi dan pers juga sudah tentu tidak terpisahkan. Artinya, karyakarya jurnalistik, baik isi, warna, semangat dan jiwanya mencerminkan konstitusi, pers yang berlaku, dan falsafah rakyat dan Negara yang bersangkutan (Amar, 1984: 37).

Sejarah mencatat dinamika pers di Indonesia mengalami beberapa kali pergantian, diantaranya yakni pers Orde Lama, Orde Baru hingga pers Reformasi. Pada masa rezim Orde Lama (1945-1965), fungsi media kala itu lebih difokuskan sebagai alat Ideologisasi dan Medium Manifesto Politik Soekarno yang merujuk pasal 2 UU Nomor 11/1966 tentang ketentuan pokok pers yang menyebutkan media sebagai bagain kekuatan progresif, revolusioner dalam menentang imperialisme, kolonialisme, neo-kolonialisme, feodalisme, liberalisme, komunisme dan fasisme/diktatur (Mukhijab, 2015). Pers kala itu hanya mengarah pada pers perjuangan, sehingga kebijakan ini secara tidak langsung menghambat pengembangan industri pers.

Era ini menandai adanya hubungan media dengan organisasi politik. Sejumlah media pada waktu itu memiliki surat kabar sendiri. Organisasi politik dan organisasi massa yang memiliki surat kabar diantaranya adalah Partai Indonesia Raya (Parindra) dengan sebelas penerbitan, Muhammadiyah empat penerbitan, dan Gerakan Rakyat Indonesia (Gerindo) dua penerbitan (Hamad, 2004 : 71).

Pada era ini, Kompas muncul di akhir masa orde lama, yakni tanggal 28 Juni 1965 sebagai media yang muncul berkat afiliasinya dengan Partai Katolik Indonesia. Kompas terkenal dengan bahasanya yang memainkan intuisi, perasaan dan emosi pembacanya. Kompas identik dengan kritik terselubung, tidak langsung dan serba tersirat, gaya yang kerap dianggap sebagai tipikal budaya Jawa (Hill, 2011 : 98).

Beralih pada masa Orde Baru (19661998) pers pada waktu itu banyak memberitakan mengenai pembangunan negara. Pers pembangunan menyampaikan dan menerangkan rencana pembangunan, program pembangunan, serta kebijaksanaan pembangunan sehingga seluruh masyarakat menurut tingkatan dan kepentingannya mengetahui serta memahami seluruh program dan masalahmasalah pembangunan (Rachmadi, 1990: 87). Pers saat itu menjadi terompet penguasa, pers digunakan sebagai alat untuk mengontrol masyrakat. Berita-berita yang beredar pada masa itu banyak yang disetir oleh pemerintah, pemberitaan tidak boleh mengkritik pemerintah jika tidak ingin terkena ayunan sapu bredel penguasa Orde Baru. Media pada masa itu benarbenar tidur dari fungsinya sebagai pilar keempat sebuah Negara.

Pada masa Orde Baru inilah Republika hadir melalui Yayasan Abdi Bangsa yang dekat dengan kepentingan Islam. Republika tidak bisa dilepaskan dari Ikatan Cendekiawan Muslim Indonesia (ICMI). Melalui prakarsa ICMI, Republika lahir menyemarakkan media tanah air pada tanggal 4 Januari 1993. ICMI bukan hanya sekedar ikatan Muslim biasa, ikatan ini amat efektif sebagai mekanisme menetralkan politik Islam serta menyalurkan ide-ide yang telah disaring ke dalam kebijakan pemerintah (Hill 2011 : 198).

Pada masa ini media dituntut untuk bersikap manis pada pemerintah apabila tidak ingin dibredel oleh penguasa, di masa inilah Kompas terkenal dengan isilah jurnalisme kepiting. Istilah jurnalisme kepiting adalah olok-olokan dari Rosihan Anwar pada Kompas (St. Sularto dalam Kurniawan dan Nurcahyo, 2013 : 78). Kepribadian Kompas bergerak ala kepiting, 
mencoba melangkah setapak demi setapak untuk mengetes seberapa jauh kekuasaan memberikan toleransi kebebasan pers yang ada. Jika aman, kaki kepiting bisa maju beberapa langkah, jika kondisi tidak memungkinkan, kaki kepiting pun bisa mundur beberapa langkah.

Walau sempat mengalami pemberhentian sementara, akibat berani berurusan dengan rezim penguasa kala itu, nyatanya Kompas masih bertahan. Melalui kehati-hatiannya, Kompas malah makin bertambah besar ketika masa jurnalisme kepiting pada paruh dekade 90-an telah berlalu. (Zulfaningrum, 2014 : 241).

Memasuki era Reformasi tahun 1998, konten berita mulai tidak seragam, sesuai dengan apa yang pemerintah inginkan. Pilihannya menjadi beragam, fase inilah yang menjadi gerbang awal kebebasan media. Kini pada era keterbukaan, rakyat Indonesia termasuk jurnalis juga mulai menikmati kebebasan berbicara, berkumpul dan berorganisasi. UU Pers diperbaiki dengan UU. 40 tahun 1999 tentang Pokok Pers, dihilangkannya pembredelan pers oleh negara, dibukanya kesempatan untuk mendirikan pers dan media elektronik (Hidayatullah, 2016: 71).

Dinamika perkembangan pers di Indonesia bersifat dinamis, teknologi media yang digunakan dalam pers juga semakin berkembang dari jaman ke jaman, mulai dari cetak, radio, audiovisual sampai dengan menggunakan media daring (online). Dekade 1990-an menandai kebangkitan media online yang terjadi bersamaan dengan perubahan teknologi dari analog menjadi digital (Junaedi, 2014 : 13)

Kini di era globalisasi, pers Indonesia tidak lagi membahas mengenai pers perjuangan yang menghadirkan tokohtokoh pejuang kemerdekaan dan pers pembangunan yang banyak menjadi liputan pers Orde Baru yang berlandaskan pancasila. Kisah-kisah tokoh pers berubah menjadi komoditas, globalisasi menyambungkan ekspansi kultur campur ekonomi ke banyak wilayah. Batas-batas geografis politis, kebangsaan, kenegaraan dan lainnya luntur. Dunia menjadi sedatar piring (Septiawan, 2017 : 318).

Menrut Rianto dalam Alwajih (2012 : 80-81) konteks jurnalisme saat ini tidak bisa terlepas dari paham neoliberalisme yang telah mengakar kuat dalam tatanan ekonomi global (WTO, IMF, Bank Dunia, dan jejaring global governance). Produk jurnalisme adalah bagian penting dari output media yang memiliki nilai ekonomi, sehingga harus mampu menggeruk keuntungan. Kondisi ini membuat jurnalisme tenggelam dalam apa yang disebut market-driven journalism, jurnalisme yang dikendalikan pasar.

Peran pers dalam menyajikan berita juga turut andil dalam prosesnya menuliskan sebuah berita, organisasi media yang berada dibalik terbentuknya berita tidak lepas dari kepentingannya. Faktor-faktor yang memengaruhi media dalam proses produksi berita (Shoemaker \& Reese, 1996) pada penelitian ini mencakup dua level, yakni pada level organisasi dan level ekstramedia. Kedua level ini menunjukkan bahwa sebagai bisnis komersil, harian Kompas dan Republika dalam memproduksi berita tetap tidak bisa lepas dari profit.

Hal ini memperlihatkan bahwa selera masyarakat sangat berperan dalam keberlangsungan media. Isu yang sedang menarik perhatian khalayak, seperti isu politik pada masa reformasi misalnya dengan mudah mendapatkan perhatian khalayak. Konsumsi khalayak terhadap media yang mengedepankan isu politik yang mengemuka di masa ini memperkuat premis mengenai relasi antara selera khalayak dengan kehidupan media (Junaedi, $2014:$ 24).

\section{B. METODE PENELITIAN}

Penelitian ini termasuk ke dalam jenis penelitian kualitatif, menurut Salim penelitan kualitatif merupakan suatu metode berganda dalam fokus yang melibatkan pendekatan interpretatif terhadap setiap pokok permasalahan yang dikajinya (Salim, 2005 : 34). Pada penelitian ini, data yang akan dikumpulkan dengan teknik dokumentasi. Menurut Moleong, 
teknik dokumentasi dapat dilakukan dengan mempelajari dokumen-dokumen serta catatan yang memiliki hubungan dengan unit analisis, sehingga nantinya dapat dipakai untuk melengkapi data yang dibutuhkan dalam penelitian (Moleong, 1997 : 161). Terdapat dua jenis data dalam penelitian ini, yakni data primer dan data sekunder (Suryabrata, 2003 : 38-30), sumber data primer untuk penelitian ini diambil dari berita yang membahas mengenai pengungsi Rohingnya di kedua surat kabar harian Nasional yakni Kompas dengan edisi 7, 6 dan 11 September 2017, sementara Republika pada edisi 7, 8 dan 10 September 2017. Sampel berita lihat Tabel 1 dan Tabel 2 yang disajikan dapat mencerminkan falsafah hidup organisasi dari media.

Tulisan ini juga mengambil sumber data sekunder yang berasal dari 17 buku dan 10 jurnal penelitian sebagai pendukung data penelitan bagi penulis. Penggunaan font tebal (bold) untuk kata atau kalimat yang dirasa perlu penekanan. Berita-berita ini akan dianalisis menggunakan model analisis framing milik Zhongdang Pan dan Gerald M. Kosciki.

Tabel 1. Headline Berita Harian Kompas Mengenai Pengungsi Rohingnya

\begin{tabular}{cl}
\hline No. & Edisi \\
\hline 1. & 7 September 2017 \\
& Suu Kyi Mengecam Disinformasi \\
2. & 6 September 2017 \\
& RI Siap Membantu Banglades \\
3. & 11 September 2017 \\
& Meniti Jalan Perdamaian Rohingnya \\
\hline
\end{tabular}

Tabel 2. Headline Berita Harian Republika Mengenai Pengungsi Rohingnya

\begin{tabular}{cl}
\hline No. & Edisi \\
\hline 1. & 7 September 2017 \\
& Suu Kyi Bungkam \\
2. & Edisi 8 September 2017 \\
& Krisis Rakhine Masuk Deklarasi Bali \\
3. & Edisi 10 September 2017 \\
& Republika Gelar Puisi Cinta Untuk Rohin- \\
gnya
\end{tabular}

\section{PEMBAHASAN}

\section{Analisis Bingkai Pemberitaan Harian Kompas}

1. Frame: Klaim Myanmar Lindungi Penduduk Rohingnya

Headline: Suu Kyi Mengecam Disinformasi

Tanggal Terbit: 7 September 2017

\section{Struktur Sintaksis}

\begin{tabular}{l}
\hline Lead \\
\hline Setelah berdiam diri cukup lama, Menteri Luar \\
Negeri yang juga penasihat Negara Myanmar \\
Aung San Suu Kyi, Rabu (6/9) mengeluarkan \\
pernyataan soal kondisi yang menimpa warga \\
Rohingnya di Negara Bagian Rakhine. Suu Kyi \\
mengecam disinformasi yang beredar dan \\
menegaskan bahwa Pemerintah Myanmar \\
melindungi semua warga Rakhine.
\end{tabular}

\section{Latar Informasi}

Suu Kyi mengecam disinformasi yang dinilainya dapat merusak hubungan antarnegara. Disinformasi yang dimaksud adalah foto-foto yang diunggah melalui Twitter oleh Perdana Menteri Turki Mehmet Simsek pada 29 Agustus.

\section{Kutipan, Sumber, Pernyataan}

- "Informasi palsu seperti itu, sebagaimana pernyataan wakil PM, termasuk puncak dari gunung es disinformasi yang dapat menimbulkan masalah antarnegara dan seiring dengan tujuan yang diinginkan teroris," kata Kemlu Myanmar.

- Tidak dijelaskan apa yang dimaksud sebagai teroris itu. Namun, otoritas Myanmar menyatakan militer tengah berupaya menghancurkan kelompok teroris yang dianggap bertanggung jawab atas serangan terhadap sejumlah pos polisi dan militer Myanmar sejak Oktober 2016.

- Jumlah pengungsi Rohingnya ke Banglades, menurut PBB telah mencapai 146.000 orang atau mencapai 233.000 orang. Jumlah mereka diprediksi terus bertambah mengingat belum jelasnya kondisi di Rakhine.

\section{Penutup}

Unjuk rasa memprotes kekerasan yang terjadi pada warga Rohingnya terus bergulir di Tanah Air. Unjuk rasa dan seruan damai juga dilakukan di Medan, Jambi dan Bandung. 
Frame dalam berita ini berisi klaim dari pemerintah Myanmar yang telah melindungi segenap warga negaranya. Pengggunaan kalimat, Suu Kyi mengecam disinformasi yang beredar dan menegaskan bahwa Pemerintah Myanmar melindungi semua warga Rakhine. menjadikan posisi pengungsi Rohingnya yang pergi meninggalkan Rakhine, karena mengalami kejahatan kemanusiaan seakan tidak pernah terjadi. Akibatnya pada penutup, pernyataan Suu Kyi yang klaim telah melindungi seluruh warga Negaranya mengundang sejumlah aksi.

Pada unsur skrip, frame kali ini lebih banyak membahas mengenai unsur what, who, dan why. Disebutkan beberapa tokoh internasional yang turut prihatin atas krisis kemanusiaan Rohingnya. Selain itu, terdapat pernyataan Suu Kyi yang menyatakan bahwa militer Myanmar melakukan serangan tersebut untuk menghancurkan teroris, tetapi fakta di lapangan mengatakan bahwa penduduk Rohingnya melarikan diri ke Banglades pasca seragan balasan dari militer Myanmar yang tidak proporsional di desa-desa mereka. Pernyataan ini terkesan ambigu, sebab bukan hanya teroris yang diserang, pengungsi Rohingnya juga menjadi korban. Tema besar dalam frame ini adalah pernyatan pemerintah Myanmar yang mengundang respon negatif masyarakat Indonesia yang berujung pada unjuk rasa.

Kemudian pada unsur retoris, berita ini menggunakan leksikon yang menampilkan pernyataan dari salah satu sumber PBB yang tidak disebutkan namanya. Berikut kalimatnya:

"Banglades merasa putus asa terkait isu Rohingnya. Banglades merasa sangat kesepian," kata sumber itu.

Penggambaran kata putus asa yang ditujukan pada Banglades seakan mengatakan bahwa bantuan-bantuan yang diberikan oleh Negara lain dan lembaga kemanusiaan seperti idak bermakna. Semakin diperjelas pada kata kesepian yang membenarkan kata putus asa, bahwa pihak internasional yang dalam hal ini turut membantu, sepertinya tidak banyak memberikan pengaruh pada pemerintah Banglades dalam menangani pengungsi Rohingnya.

2. Frame: Keberhasilan Pemerintah Indonesia Tangani Krisis Kemanusiaan Rohingnya

Headline: RI Siap Membantu Banglades Tanggal Terbit: 6 September 2017

\section{Struktur Sintaksis}

\begin{tabular}{l}
\hline Lead \\
\hline Di tengah arus deras kecaman dunia terhadap \\
krisis kemanusiaan Rakhine, Indonesia aktif \\
hadir dan melibatkan diri dalam diplomasi \\
kemanusiaan. Pemerintah RI juga akan melobi \\
para kepala Negara, melalui Organisasi Kerja \\
Sama Islam (OKI) dan PBB untuk membantu \\
penyelesaian krisis.
\end{tabular}

\begin{tabular}{l} 
Latar Informasi \\
\hline Wartawan Kompas, B Josie Susilo Hardianto, \\
melaporkan dari Dhaka, Banglades, seusai \\
diterima PM Sheikh Hasina, Retnomenegaskan, \\
krisis kemanusiaan di Rakhine harus diakhiri. \\
Untuk itu, Indonesia siap berbagi beban \\
dengan Banglades.
\end{tabular}

\section{Kutipan, Sumber, Pernyataan}

"Kami akan terus membicarakan bentuk bantuan apa dari Indonesia yang bisa meringankan beban Pemerintah Banglades," kata Retno.

\begin{tabular}{l}
\hline Penutup \\
\hline "(Langkah itu) sudah maksimal dan kita \\
dukung terus," ujar Ketua Forum Kerukunan \\
Umat Beragama Provinsi Sulawesi A Rahim \\
Yunus seusai menggelar pertemuan dengan \\
sejumlah pihak terkait.
\end{tabular}

Headline berita pada frame ini yang menunjukkan keseriusan Indonesia dalam mengatasi krisis kemanusiaan Rohingnya. Keberhasilan itu disampaikan pada latar informasi yang merupakan buah dari keberhasilan diplomasi kemanusiaan yang dilakukan oleh Menlu Retno LP Marsudi. Kemudian diperkuat lagi dengan pernyataan dari Menlu Retno dan ditutup dengan kutipan dari salah satu anggota aksi dari Forum Kerukunan Umat Beragama Provinsi Sulawesi Selatan yang menyatakan 
langkah pemerintah Indonesia sudah maksimal. Selanjutnya pada unsur skrip yang ditonjolkan adalah what dan who. Terlihat dari struktur sintaksis yang ditampilkan dari headline sampai dengan penutup, dalam hal kesiapan pemerintah Indonesia membantu Banglades yang disampaikan oleh sejumlah narasumber, mulai dari Menlu Retno LP Marsudi, Wartawan Kompas B Josie Susilo Hardianto sampai pada anggota aksi.

Kemudian pada unsur tematik yang dapat dilihat dari frame kali ini adalah koherensi, yaitu jalinan antar kalimat yang disampaikan dalam struktur sintaksis dengan penggunaan lead, kutipan dan juga penutup. Sementara pada unsur retoris, menampilkan grafis foto yang menggambarkan ketidakberdayaan pengungsi Rohingnya.

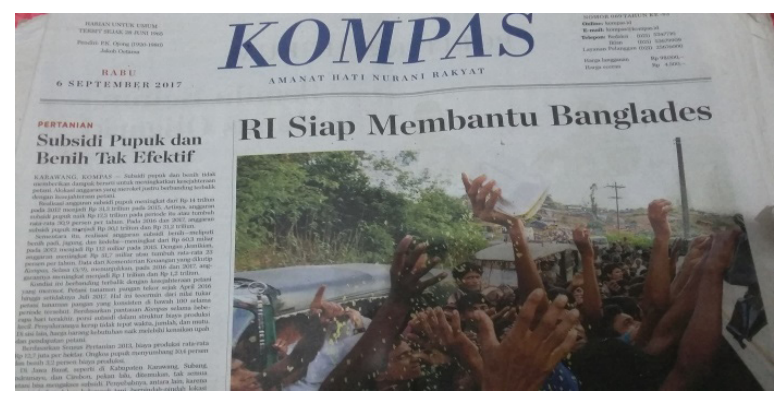

Gambar 1. Halaman utama Kompas Edisi 6 September 2017

Pada foto ini menunjukkan pengungsi Rohingnya yang berjubel sambil menadahkan tangan untuk meminta makanan di tempat penampungan. Beberapa pengungsi tampak berebut makanan dan berdesak-desaakan dengan pengungsi yang lain. Sejumlah kotak makanan yang diberikan layaknya piring terbang, terpotrettengah diraih oleh tangantangan pengungsi Rohingnya dengan tutup kotak makanan yang sedikit terbuka, sehingga mengakibatkan isinya yang sedikit berhamburan mengenai wajah mereka. Gambar ini menjelaskan penderitaan pengungsi Rohingnya yang kesulitan, hanya untuk memenuhi kebutuhan pangan.

3. Frame: Waspadai Krisis Kemanusiaan Rohingnya Terjadi di Indonesia
Headline: Meniti Jalan Perdamaian Rohingnya

Tanggal Terbit: 11 September 2017

\section{Struktur Sintaksis}

\begin{tabular}{l}
\hline Lead \\
\hline Konflik yang terjadi di Rakhine, Myanmar, sejak \\
bertahun-tahun lalu telah menggugah solidaritas \\
kemanusiaan di seluruh dunia. Selain lewat \\
bantuan kemanusiaan, publik menilai upaya \\
penyelesaian krisis juga harus ditempuh melalui \\
diplomasi yang aktif, rasional dan terukur.
\end{tabular}

\section{Latar Informasi}

- Pemberitaan krisis Rakhine cukup banyak diikuti publik di tanah air. Delapan dari 10 responden mengikuti pemberitaan terkait krisis Rakhine. Seperempat responden bahkan mengaku mengikutinya secara intens.

- Selain sorotan terhadap sisi kemanusiaannya, fokus perhatian publik juga pada kekhawatiran konflik serupa terjadi di Indonesia.

\begin{tabular}{l} 
Kutipan, Sumber, Pernyataan \\
\hline - Lebih dari 56 persen menilai langkah \\
pemerintah menyikapi krisis Rakhine sudah \\
memadai. \\
- Mayoritas responden 91 persen menilai \\
upaya diplomasi merupakan jalan efektif \\
yang bisa dilakukan untuk menghentikan \\
kekerasan. \\
- Tidak heran jika saat ini lebih dari sepertiga \\
responden meyakini perbedaan agama \\
menjadi penyebab krisis. Melihat eskalasi \\
konflik yang terjadi, bukan tidak mungkin \\
konflik di Rakhine akan berdampak ke \\
Indonesia.
\end{tabular}

\begin{tabular}{l}
\hline Penutup \\
\hline Langkah antisipasi juga harus dilakukan \\
pemerintah dalam menjaga stabilitas \\
keamanan dan keseimbangan toleransi dalam \\
negeri dari dampak konflik di Myanmar. Hal \\
ini karena sentimen etnis dan agama mudah \\
diprovokasi untuk membenamkan masyarakat \\
dalam konflik berkepanjangan. \\
\hline
\end{tabular}

Frame ini membahas mengenai adanya pengaruh krisis kemanusiaan Rohingnya pada masyarakat Indonesia. Apabila dibaca sekilas, headline pada berita edisi 11 September 2017 ini mengarah pada penduduk Rohingnya, tetapi isi dari berita 
ini membahas mengenai jajak pendapat yang dilakukan oleh Kompas, dilihat dari bingkai politik, kemanusiaan dan agama. Lead ini tidak menghianati headline 'Meniti Jalan Perdamaian Rohingnya,' sebab disebutkan bahwa upaya penyelesaian dan perdamaian dapat dilakukan dengan diplomasi. Penguatan frame ini diperlihatkan pada seperempat dari jumlah responden yang mengikuti berita krisis kemanusiaan Rohingnya secara intens. Pada akhir dari berita, Kompas mencoba memberikan kesimpulan berupa solusi untuk dapat diterapkan bagi pemerintah Indonesia agar tidak mengalami peristiwa yang serupa, mengingat Myanmar dan Indonesia memiliki kedekatan secara demografis, yakni samasama dihuni masyarkat yang plural dalam beragama.

What, who dan how merupakan unsur skrip yang ditonjolkan. Membahas mengenai penderitaan yang dialami oleh pengungsi Rohingnya, kemudian sejumlah pihak yang bereaksi terhadap krisis kemanusiaan Rohingnya dan bagaimana peristiwa ini memberikan dampak bagi masyarakat internasional, termasuk Indonesia yang memberikan perhatian dalam krisis kemanusiaan Rohingnya, dari sisi pemerintah maupun rakyatnya. Adapun tema yang dipakai dalam struktur tematik frame adalah bagaimana jajak pendapat yang dilakukan oleh Kompas ini memiliki pengaruh pada sikap masyarakat Indonesia. Susunan paragraf pada berita didominasi oleh hasil dari jajak pendapat yang dinarasikan. Struktur retoris dalam berita menggunakan infografis yang memuat hasil dari jajak pendapat yang dilakukan oleh Kompas.

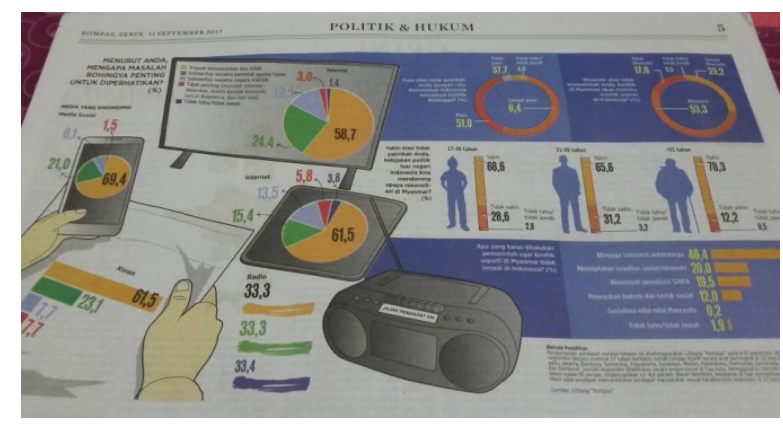

Gambar 2. Infografis Kompas Mengenai Pengungsi Rohingnya
Infografis ditampilkan berwarna dengan memuat beberapa pertanyaan beserta jawaban yang disajikan dalam bentuk chart, lengkap dengan presentase. Responden yang dipilih Kompas sebanyak 459 orang dengan usia minimal 17 tahun yang dipilih secara acak di 12 kota besar di Indonesia, meliputi Jakarta, Bandung, Semarang, Yogyakarta, Surabaya, Medan, Palembang, Pontianak, Samarinda, Manado, Makassar dan Denpasar.

\section{Analisis Bingkai Pemberitaan Harian Republika}

1. Frame: Kekecewaan Dunia Internasional Pada Aung San Suu Kyi

Headline: Suu Kyi Bungkam

Tanggal Terbit: 7 September 2017

STRUKTUR SINTAKSIS

\begin{tabular}{l} 
Lead \\
\hline Pemimpin de facto Myanmar Aung San \\
Suu Kyi akhirnya angkat bicara terkait krisis \\
kemanusiaanyang terjadidi Rakhine, Myanmar. \\
Akan tetapi, peraih Nobel Perdamaian pada \\
1991 ini sama sekali tidak menyinggung \\
kelompok minoritas Muslim Rohingnya yang \\
menjadi korban kekejaman militer Myanmar. \\
Latar informasi \\
Dari Perbatasan Myanmar-Banglades \\
dilaporkan, gelombang Muslim Rohingnya \\
yang mengungsi belum juga berhenti. Selain \\
pengungsian di Cox's Bazar dan Kutupalong, \\
mereka berbondong-bondong menuju \\
Shamlapur, Banglades. Para pengungsi \\
berupaya mencari perlindungan dari persekusi \\
oleh militer Myanmar.
\end{tabular}

Kutipan, Sumber, Pernyataan

Menurut Aliansi Pergerakan Islam Jawa Barat Wawan Gunawan, terdapat tiga tuntutan yang disampaikan peserta aksi, salah satunya meminta Indonesia memutuskan hubungan diplomatik dengan Myanmar.

\begin{tabular}{l}
\hline Penutup \\
\hline Selain di Jakarta, aksi solidaritas juga \\
dilaksanakan di Medan (Sumatera Utara), \\
Banyuasin (Sumatra Selatan), dan Bandar \\
Lampung (Lampung), Para peserta aksi juga \\
menyampaikan kecaman atas kekejaman \\
militer Myanmmar.
\end{tabular}


Struktur skrip pada frame ini membahas mengenai Aung San Suu Kyi sebagai Pemimpin de facto Myanmar. Kekecewaan masyarakat internasional ditampilkan oleh Republika dengan headline berbau negatif yang ditujukan pada Suu Kyi dengan menyematkan kata 'bungkam' dalam headline. Sikap bungkam Suu Kyi ini mengarah pada kekecewaan masyarakat, sebab apa yang dilakukan Suu Kyi tidak sesuai dengan harapan banyak pihak. Suu Kyi dinilai memiliki posisi strategis yang bisa membantu pengungsi Rohingnya, tetapi posisi itu tidak dimanfaatkan dengan baik. Hal inilah yang semakin memperkuat bingkai pemberitaan Republika yang kemudian diikuti aksi solidaritas di Indonesia yang menjadi sarana bagi para anggota aksi untuk menyampaikan tuntutan, berita ini kemudian ditutup dengan penjelasan mengenai sejumlah lokasi diadakannya aksi.

Struktur skrip pada frame kali ini lebih banyak membahas mengenai what, who dan how. Penonjolan ketiga unsur ini ditampilkan dalam ketiga berita dengan menuliskan banyaknya tokoh internasional yang memberikan tanggapan kepada Myanmar, khusunya kepada Aung San Suu Kyi untuk segera bertindak sesuai dengan kapasitasnya sebagai peraih Nobel Perdamaian. Adapun struktur tematiknya berkaitan dengan sikap Aung San Suu Kyi yang mengundang kekecewaan dunia internasional. Pemilihan kalimat dalam frame kali ini menyudutkan Aung San Suu Kyi sebagai peraih nobel perdamaian yang tidak memperjuangkan hak asasi pengungsi Rohingnya yang tengah mengalami krisis kemanusiaan di Myanmar.

Sementara pada unsur retorisnya, frame kali ini menampilkan grafis berupa gambar sekumpulan peserta aksi solidaritas untuk Rohingnya di Bundaran Hotel Indonesia (HI) Jakarta. Gambar ini diambil dari atas yang menunjukkan kemegahan aksi yang dilakukan oleh peserta aksi, sekumpulan peserta aksi menggenakan baju berwarna putih dan ada juga yang mengenakan baju warna merah, memperlihatkan kesatuan bangsa dalam merah-putih Indonesia untuk menolong pengungsi Rohingnya.
2. Frame: Indonesia Perlu Desak Myanmar untuk Akhiri Kekerasan di Rakhine:

Headline: Krisis Rakhine Masuk Deklarasi Bali

Tanggal Terbit: 8 September 2017

\section{STRUKTUR SINTAKSIS}

\begin{tabular}{l} 
Lead \\
\hline Krisis kemanusiaan di Rakhine menjadi bagian \\
dari Deklarasi Bali dalam forum parlemen dun- \\
ia yang secara resmi ditutup pada Kamis (7/9). \\
\hline Latar Informasi \\
\hline Ketua Badan Kerjasama Antarparlemen DPR RI, \\
Nurhayati Ali Assegaf menjelaskan forum yang \\
mengangkat tema "Pembangunan berkelanju- \\
tan" itu menyepakati perihal hak asasi manusia \\
(HAM).
\end{tabular}

Kutipan, Sumber, Pernyataan

Wakil Ketua DPR RI, Fadli Zon, "Menurut pendapat saya, jika pemerintah berani, maka Indonesia harus membuka diri. Ya, itu termasuk naturalisasai untuk pengungsi Rohingnya di pulau-pulau tertentu yang bisa kita siapkan, kata Fadli di sela-sela forum Parlemen Dunia Nusa Dua, Bali, Kamis (7/9).

\begin{tabular}{l}
\hline Penutup \\
\hline Dia mengaku secara pribadijuga akan melaku- \\
kan pendekatan pada Banglades, Negara \\
tetangga terdekat Myanmar. Dia dan Menteri \\
luar negeri Banglades bahkan sempat beren- \\
cana melihat lokasi pengungsian etnis Rohing- \\
nya di Banglades beberapa waktu lalu. \\
\hline
\end{tabular}

Krisis kemanusiaan Rohingnya menjadi hal yang dibahas dalam forum Deklarasi Bali. Pernyataan yang disampaikan Wakil Ketua DPR RI Fadli Zon secara eksplisit mengharapkan pemerintah untuk bertindak lebih jauh dalam menjadikan pengungsi Rohingnya sebagai bagian dari warga Negara ini. Di luar forum, Republika juga menampilkan upaya pribadi Fadli Zon dalam membantu pengungsi Rohingnya.

Struktur skrip yang ditampilkan pada frame ini adalah unsur what dan how mengenai pengaruh yang terjadi atas adanya krisis kemanusiaan Rohingnya. Kekerasan yang terjadi di Rakhine membuat dunia internasional menyoroti apa yang sebenarnya terjadi di Myanmar. Dijelaskan 
mengenai apa dan bagaimana upaya anggota forum dapat membantu pengungsi Rohingnya. Kemudian tema besar yang disajikan dalam frame yakni menunjukkan keseriusan Indonesia dalam membantu pengungsi Rohingnya yang ditunjukkan dengan upaya pribadi oleh Wakil DPR RI Fadli Zon. Deklarasi Bali ini menjelaskan bahwa sebanyak 49 negara dalam forum tersebut sepakat untuk memberi dukungan penyelesaian krisis kemanusiaan di Myanamar.

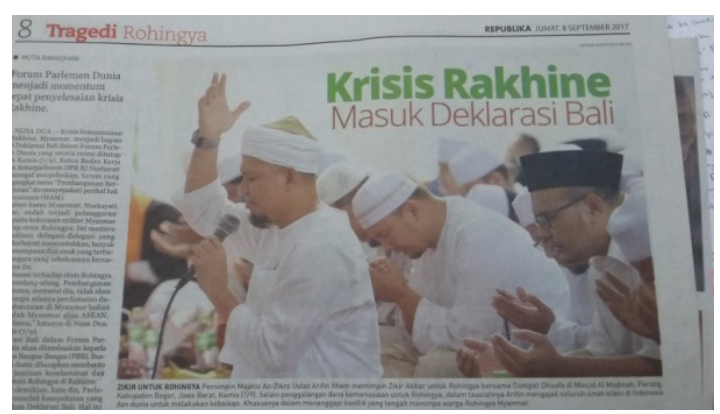

Gambar 3. Dzikir Bersama Ustadz Arifin Ilham (Republika edisi 8 September 2017)

Unsur retoris ini menampilkan gambar Pimpinan Majelis Az-Zikra Ustadz Arifin Ilham yang memimpin Zikir Akbar untuk pengungsi Rohingnya dengan sudut foto yang diambil dari samping, potret Ustadz Arifin llham yang mengangkat tangan kanan, sementara kanan kiri memegang microphone untuk berdoa dengan diikuti di belakangnya jamaah Masjid Al Madinah, Parung, Kabupaten Bogor, Jawa Barat yang juga mengangkat kedua tangan mereka.

3. Frame: Dukungan Masyarakat Indonesia untuk Pengungsi Rohingnya.

Headline: Republika Gelar Puisi Cinta untuk Rohingnya.

Tanggal Terbit: 10 September 2017.

\section{STRUKTUR SINTAKSIS}

\begin{tabular}{l} 
Lead \\
\hline Sebuah pagelaran menyentuh hati oleh Re- \\
publika bekerja sama dengan sejumlah lemba- \\
ga kemanusiaan akan dilangsungkan malam \\
ini (10/9). Bertemakan "Puisi Cinta Untuk Ro- \\
hingnya," acara akan dihadiri oleh berbagai \\
tokoh ormas lintas agama.
\end{tabular}

\section{Latar Informasi}

Pemimpin redaksi Republika Irfan Junaedi mengungkapkan, acara ini dilaksanakan sebagai bentuk protes atas kebrutalan Pemerintah Myanmar melalui cara yang lembut dan menyentuh.

\section{Kutipan, Sumber, Pernyataan}

Pemimpin Redaksi Republika Irfan Junaedi, "Kami ingin menyampaikan sikap dengan cara yang lebih lembut," kata dia saat dihubungi Republika, Sabtu (9/9) malam.

\section{Penutup}

Halaman parkir Muhammadiyah dipilih karena posisinya strategis, mudah dijangkau dari wilayah mana pun. Dengan begitu, yang ingin hadir bisa menemukan lokasi dengan mudah.

Headline pada berita ini memperlihatkan penjelasan dari frame yang dibangun oleh Republika. Republika sebagai media penyuara umat Islam menempatkan dirinya menjadi media yang peduli dengan penderitaan pengungsi Rohingnya yang nampak dari akan diselenggarakannya panggung puisi yang bertemakan 'Puisi Cinta untuk Rohingnya.' Republika ingin menunjukkan aksi solidaritas untuk pengungsi Rohingnya dengan melakukan pembacaan puisi yang tujuannya untuk melembutkan hati siapa saja yang mendengar, bagaimana penderitaan yang dialami pengungsi Rohingnya. Pada penutup menampilkan pernyataan dari narasumber yang mengarah pada jalannya dukungan kemanusiaan yang diberikan.

Setelah itu adalah skrip yang lebih banyak membahas unsur what, dan why, diadakannya aksi solidaritas melalui pembacaan puisi sebagai simbol dari cinta dan kelembutan. Pengadaan kegiatan ini dalam rangka membantu pengungsi Rohingnya jelas menunjukkan keberpihakan Republika. Tema besar pada bingkai pemberitaan yakni bentuk tanggapan masyarakat Indonesia terhadap krisis kemanusiaan Rohingnya yang disampaikan melalui panggung seni. 


\section{ANALISA}

\section{Perbedaan Bingkai Pemberitaan Harian Kompas dan Republika Mengenai Pengungsi Rohingnya}

\begin{tabular}{clrl}
\hline No. & \multicolumn{1}{c}{ Kompas } & \multicolumn{1}{c}{ Republika } \\
\hline 1. & Klaim Myanmar Lindungi \\
& Rohingnya & Penduduk & Kekecewaan Dunia Internasional Terhadap \\
& Aung San Suu Kyi & \\
2. & $\begin{array}{l}\text { Keberhasilan Diplomasi Indonesia Atasi Krisis } \\
\text { Kemanusiaan Rohingnya }\end{array}$ & $\begin{array}{l}\text { Indonesia Perlu Desak Myanmar untuk Akhiri } \\
\text { Kekerasan di Rakhine. }\end{array}$ \\
3. $\begin{array}{l}\text { Waspadai Krisis Kemanusiaan } \\
\text { Menimpa Indonesia }\end{array}$ & Rohingnya & $\begin{array}{l}\text { Dukungan Masyarakat Indonesia untuk } \\
\text { Pengungsi Rohingnya }\end{array}$ \\
\hline
\end{tabular}

Kedua surat kabar tersebut memiliki bingkai pemberitaan yang berlainan satu sama lain. Keenam berita yang ditampilkan dalam keenam frame tersebut, tentunya dalam penyusunannya tidak lepas dari paradigma konstruksionisme. Adanya informasi dalam berita merupakan realitas yang baru, dibentuk oleh tim pembuat berita yang di dalamnya terdapat reporter dan editor. Dari sini dapat dilihat bahwa pembentukan berita dapat dipengaruhi oleh tim pembuat berita. Realitas dalam berita tentunya tidak tunggal, melainkan jamak. Sebab dapat dimaknai berbeda oleh setiap individu pembuat berita. Oleh sebab itulah terdapat perbedaan bingkai pemberitaan yang ditampilkan Kompas dan Republika mengenai pengungsi Rohingnya.

Pada perbedaan pertama yang akan ditampilkan adalah headline berita pada Kompas yang menuliskan Suu Kyi Mengecam Disinformasi, sementara Republika menuliskan dengan Suu Kyi Bungkam. Meskipun diterbitkan pada waktu yang bersaman, Kompas dan Republika melihat dari sisi yang berbeda. Pada frame ini Kompas dengan headline berita Suu Kyi Mengecam Disinformasi menampilkan pernyataan Aung San Suu Kyi sebagai pimpinan de facto Myanmar. Suu Kyi menyatakan telah melindungi seluruh warga negaranya, termasuk penduduk Rohingnya. Terlebih juga ditampilkan pernyataan Suu Kyi yang mengatakan bahwa penduduk Rohingnya tidak perlu mengungsi dari Myanmar. Seolah membela Suu Kyi dengan pernyataan yang mengklaim telah melindungi pengungsi Rohingnya, di lain sisi Kompas juga menunjukkan kalimat yang menyuarakanhakasasipengungsiRohingnya dengan kalimat redaksi yang berbunyi, 'Namun Suu Kyi tidak menyinggung arus pengungsi.' Selain itu Kompas juga mempermaslahkan penyebutan teroris pada pernyataan resmi Suu Kyi yang tidak dijelaskan secara lebih lanjut siapa yang dimaksud sebagai teroris disini. Sikap inilah yang membuat Kompas abu-abu dalam menunjukkan keberpihakannya. Sementara Republika dalam hal ini jelas menunjukkan keberpihakannya kepada pengungsi Rohingnya dengan sikap kontranya kepada pemerintah Myanmar dengan menampilkan sejumlah aksi solidaritas yang menuntut kesemalatan pengungsi Rohingnya.

Perbedaan kedua adalah narasumber yang dipilih oleh Kompas dan Republika dalam menggambarkan pengungsi Rohingnya. Apabila Kompas selalu menggunakan narasumber dengan nama besar sesuai dengan kapasitasnya dalam memberikan pernyataan, namun pada frame ini Kompas menampilkan narasumber dari kalangan masyarakat yang terlibat dalam aksi solidaritas untuk pengungsi Rohingnya yang menyatakan bahwa langkah diplomasi yang diambil pemerintah Indonesia sudah tepat. Kutipan dari Ketua Forum Kerukunan Umat Beragama Provinsi Sulawesi A Rahim Yunus "(Langkah itu) sudah maksimal dan kita dukung terus," kata maksimal disini menunjukkan kepuasan yang disampaikan oleh warga Indonesia terkait langkah diplomasi pemerintah Indonesia dalam membantu penyelesaian krisis kemanusiaan Rohingnya. Berbeda dengan Kompas, 
Republika menampilkan narasumber dari kalangan pemerintah, yakni Wakil Ketua DPR RI Fadli Zon yang dijumpai dalam forum internasional Deklarasi Bali. Republika menggambarkan bahwa Indonesia perlu bertindak lebih dalam upaya meyelematkan Pengungi Rohingnya, bukan dikatakan berhasil sampai lagkah diplomsi saja, seperti bingkai pemberitaan yang dibangun Kompas dengan menyatakan upaya pemerintah sudah maksimal dan menjadi keberhasilan diplomasi Indonesia.

Selanjutnya pada perbedaan ketiga menampilkan posisi Kompas dan Republika dalam menaggapi adanya krisis kemanusiaan Rohingnya. Kompas memunculkan berita mengenai adanya kemungkinan peristiwa krisis kemanusiaan serupa dapat terjadi di Indonesia yang dituliskan dalam berita berjudul 'Meniti jalan Perdamaian Rohingnya.' Dalam berita ini ditampilkan hasil survey oleh Kompas yang menyebutkan sebanyak 53,3\% responden khawatir, bahkan 29,2\% responden sangat khawatir krisis kemanusiaan yang serupa dapat terjadi di Indonesia, mengingat kesamaan demografis Indonesia-Myanmar yang terdiri dari pemeluk agama yang plural. Sedangkan Republika tampak bertindak lebih jauh dengan menggelar acara bertajuk 'Puisi Cinta untuk Rohingnya,' yang memperlihatkan bentuk kepedulian Republika dalam menunjukkan aksi solidaritas yang dilakukan dengan kelembutan melalui seni puisi.

Level ekstramedia dan level organisasi tentu turut berperan dalam produksi pembuatan berita. Kompas menampilkan bingkai pemberitaan pengungsi Rohingnya yang mendukung sepenuhnya gerak pemerintah dengan cara memperlihatkan upaya pemerintah dalam membantu menangani permasalahan kemanusiaan Rohingnya yang dapat dilihat dari pemilihan headline, diksi dan konten yang mewakili pemerintah Indonesia. Kompas menunjukkan kinerja baik pemerintah Indonesia dalam menangani krisis kemanusiaan Rohingnya untuk membantu menyelesaikan permaslahan kemanusiaan tersebut. Tetapi memang sudah menjadi ciri
Kompas dalam mengaburkan sikap redaksi pada berita yang disampaikan, hal ini terlihat dari dua frame yang disajikan Kompas yang seakan menggiring pembaca untuk mengantisispasi peristiwa kemanusiaan yang serupa dapat terjadi di Indonesia.

Dijuluki dengan sebutan jurnalisme kepiting, hal ini terlihat dari bahasa yang berputar-putar, membuat Kompas menjadi abu-abu dalam menentukan keberpihakannya. Kehati-hatian Kompas dalam memihak ini terlihat dari beragam frame yang dimiliki, pada suatu saat terlihat memihak pengungsi Rohingnya dengan mendukung tersalurkannya bantuan kemanusiaan, namun tiba-tiba saja membuat manuver dengan berita yang membahas kemungkinan terjadinya krisis kemanusiaan yang serupa di Indonesia, mengingat terdapat kesamaan pada IndonesiaMyanmar yang terdiri dari masyarakat plural. Bingkai pemberitaan Kompas secara garis besar adalah mengenai kesedihan bagi pengungsi Rohingnya yang kemudian menimbulkan upaya dari kalangan Nassional dan Internasional. Kompas melihat permasalahan kemanusiaan Rohingnya sebagai masalah kemanusiaan internasional yang ditilik dari sisi bantuan pemerintah Indonesia kepada Banglades dan Myanmar.

Selain itu keberpihakan Kompas kepada pengungsi Rohingnya tercermin dari empat nilai-nailai dasar Kompas yamg cenderung kepada nilai budaya kolektivistik, yakni menghargai manusia dan nilai-nilai kemanusiaan juga tercermin dalam prinsip jurnalisme humanisme transdental yang mengutamakan nilai berita sisi kemanusiaan (human interest). (Hutugalung, 2016). Maka terdapat kesamaan antara falsafah organisasi Kompas dengan unsur kemanusiaan pengungsi Rohingnya. Pada tahap inilah level organisasi turut mengendalikan berita apa yang akan ditampilkan.

Sementara Republika menempatkan permasalahan kemanusiaan Rohingnya sebagai masalah umat Islam. Jika Harian Republika banyak memuat konten Islam tentu tidak terasa aneh, mengingat media ini didirikan oleh kalangan cendekia Islam: 
Ikatan Cendekiawan Musllim Indonesia (ICMI) (Fahmi, Abdullah, Noviani dan Udasmoro, 2015 : 56).

Melalui bingkai pemberitaan yang dibangun oleh Republika, ditampilkan sejumlah kegiatan yang menunjukkan kontribusinya dalam menyuarakan hak kemanusiaan pengungsi Rohingnya yang dilalukan dengan menggelar aksi dzikir bersama, aksi solidaritas dalam pembacaan puisi dan penggalangan bantuan yang semuanya ditampilkan dalam berita. Wacana dan juga gagasan yang dituangkan oleh Republika dalam rubriknya, sesungguhnya adalah perwujudan dari ideologi yang ingin disampaikan oleh Republika. Namun, sebagai pers Islam yang bersifat media umum, Republika tidak dapat meninggalkan ideologi keislamannya dan juga berusaha menjunjung humanisme universal (Ulfah, 2017 : 49).

Selain itu, sisi kemanusiaan begitu memainkan emosi karena sifatnya yang universal. Hal ini semakin terbukti dengan adanya perhatian masyarakat Indonesia pada berita yang datang dari Negara timur tengah. Pemberitaan mengenai perang teluk pada tahun 1990 menggambarkan penderitaan manusia dalam masa peperangan, hingga akhirnya menarik minat baca masyarakat Indonesia. Penjualan seluruh surat kabar pada masa itu mengalami lonjakan yang signifikan.

Kompas terjual habis sampai-sampai cetak ulang sampai sekitar 700.000. Loperloper koran di jalan kehaisan stok, surat kabar-surat kabar seharga Rp 250 ludes terjual dengan harga Rp 1.000. Bahkan penjualan surat kabar kecil pun ikut terkerek (Hill, 2011 : 174).

Pada perang Teluk (Amerika Serikat melawan Iran mengenai masalah Kuwait), media massa kembali memainkan kekuatannya sebagai alat penyebar informasi. Disebabkan begitu besarnya andil massa dalam perang Teluk, beberapa ahli komunikasi mengatakan bahwa perang Teluk termasuk dalam perang media massa. Fakta ini membuktikan bahwa publikasi massa efektif untuk memengaruhi tingkah laku dan juga opini publik, serta juga dapat mempereratjalinan antar bangsa. Hal ini bisa terjadi, sebab media massa memiliki sifat daya jangkau khalayak yang luas, bahkan mungkin tidak terbatas secara geografis maupun kultural (Hutugalung, 2016 : 4).

Kondisi inilah yang membuat pers Indonesia menguat di pasaran, pemberitaan yang dilihat dari sisi keagamaan maupun kemanusiaan tanpa sadar dapat menarik minat pembaca, hingga meningkatkan angka penjualan.

\section{E. KESIMPULAN}

Krisis kemanusiaan yang menimpa pengungsi Rohingnya di bingkai dalam dua bingkai pemberitaan yang berbeda. Oleh Kompas, sisi kemanusiaan Rohingnya dilihat sebagai permasalahan intenasional. Sementara oleh Republika, sisi kemanusiaan Rohingnya ditampilkan sebagai masalah umat Islam. Tiga bingkai pemberitaan yang ditampilkan oleh Kompas dan Republika memiliki perbedaan dari sisi headline, narasumber yang ditampilkan dan sikap kedua media dengan adanya survey dari Kompas dan pagelaran puisi dari Republika. Tetapi lebih dari itu, adanya ketertarikan berita mengenai isu universal menjadi perhatian bagi pasar media yang sempat terjadi pada awal tahun 1990, dengan adanya pemberitaan mengenai Perang Teluk. Sebab, bagaimanapun juga organisasi media merupakan kepentingan bisnis yang tidak bisa lepas dari makna profit dengan tetap memerhatikan level organisasi dan level ekstramedia.

Ketika krisis kemanusiaan Rohingnya terjadi, Kompas terlihat berimbang dengan berada pada dua posisi, namun tetap dalam posisinya mendukung pemerintah. Berbeda dengan Republika yang jelas menunjukkan keberpihakannya, Republika konsisten untuk mendukung keselamatan pengungsi Rohingnya dengan berupaya melakukan desakan kepada pemerintah agar dapat bertindak lebih. Keberpihakan kedua media kepada pengungsi Rohingnya ditampilkan secara berbeda, kedua media melihat sisi kemanusiaan dalam pengungsi Rohingnya 
juga berbeda. Kompas puas dengan diplomasi kemanusiaan yang dilakukan pemerintah. Sedangkan Republika menginginkan bukan hanya sekedar diplomasi kemanusiaan, melainkan sampai dengan mengupayakan keselamatan pengungsi Rohingnya agar hidup lebih baik.

\section{REFERENSI}

Alwajih, Ahmad (2012), Jurnalisme Profesional Pilar Demokrasi ?: Analisis Kritis Perspektif Anthony Gidddens, Jurnal Komunikasi, Vol. 7 No. 1 : 80-81

Amar, M. Djen. (1984). Hukum Komunikasi Jurnalistik. Bandung: Penerbit Alumni..

Eriyanto. (2002). Analisis Framing : Konstruksi, Ideologi, dan Politik Media. Yogyakarta: LKiS

Fahmi, Muhammad; Abdullah, Irwan; Noviani, Ratna dan Udasmoro, Wening (2015), Diskursus Islam Dalam Konstruksi Media, Jurnal Lingua, Vol. 10 No. 02 : 56

Flournoy, Don Michael (1989). Analisisi Surat kabar Surat Kabar Indonesia. Yogyakarta: Gadjah Mada University Press

Hamad, I. (2004). Konstruksi Realitas Politik dalam Media Massa. Jakarta: Granit

Harahap, Krisna. (2000). Kebebasan Pers di Indonesia: dari Masa ke Masa. Bandung: Grafitri

Hidayatulah. (2016). Jurnalisme Cetak (Konsep dan Praktik). Yogyakarta: Buku Litera Yogyakarta

Hill, David. T. (2011). Jurnalisme dan Politik di Indonesia. Jakarta: Yayasan Pustaka Obor Indonesia

Hutugalung, Inge (2016), Budaya Organisasi Dan Dinamika Ruang Redaksi, Jurnal Interaksi, Vol. 05 No. $01: 4$

Junaedi, Fajar. (2014). Manajemen Media Massa: Teori, Aplikasi dan Riset. Yogyakarta: Buku Litera

K. Septiawan, Santana. (2017). Jurnalisme Kontemporer. Jakarta: Yayasan Pustaka Obor Indonesia

Kurniawan, Andik dan Nurcahyo, Abraham (2013), Pengaruh Dinamika Politik Indonesia Terhadap Eksistensi Harian Kompas (1965-2012), Jurnal Agastya, Vol. 03 No. 01 : 94

Mangku, Dewa Gede Sudika (2013), Kasus Pelanggaran HAM Etnis Rohingnya: Dalam Perspektif ASEAN. Jurnal Media Komunikasi FIS, Vol. 12 No. 2 : 25-40

Moleong, L. J. (1997). Metodologi Penelitian Kualitatif. Bandung: PT Remaja Rosdakarya

Mubarok dan Adnjani (2012), Konstruksi Pemberitaan Media tentang Negara Islam Indonesia (Analisis framing Republika dan Kompas. Jurnal Komunikasi Makna, Vol. 3 No. 1 : 181 196

Mukhijab (2015), Membaca Relasi Media Pemerintah Pada Era Otonomi Daerah. Jurnal Komunikator, Vol. 7 No. $2: 106$

Muda, D.I. (2003) Jurnalistik Televisi : Menjadi Reporter Profesional. Bandung: PT Remaja Rosdakarya

Narendra, P. (2008). Metodologi Riset Komunikasi. Yogyakarta: BPPI Yogyakarta dan Pusat Kajian Media \& Budaya Populer.

Rachmadi. F. (1990). Perbandingan Sistem Pers. Jakarta: PT Gramedia 
Salim, Agus. (2005). Teori \& Paradigma Penelitian Sosial. Yogyakarta : Penerbit Tiara Wacana

Shoemaker, Pamela J. , Stephan D. Reese (1996). Mediating The Message : Second Edition. USA: Longman Publishers USA

Suryabrata, Sumadi. (2003). Metodologi Penelitian. Jakarta: PT Rajagrafindo Persada

Ulfah, Maria Novi (2017), Framing Media Dan Penistaan Agama: Studi Kasus Tajuk Rencana Harian Republika dan Kompas. Jurnal SMaRT, Vol. 03 No. 2 : 249

Wahyudi, J. B (1987). Komuniaksi Jurnalistik: Pengetahuan Praktis Kewartawanan, SuratkbarMajalah, radio \& Televisi. Jakarta: Penerbit Alumni.

Yumitro, Gonda (2017), Respon Dunia Internasional terhadap Tragedi Kemanusiaan Rohingnya. Jurnal Sospol, Vol. 3 No. 2 : 81-96

Zulfaningrum, Rahmawati (2014), Spesialisasi Dan Praktik Konglomerasi Media Kelompok Kompas Gramedia. Jurnal ASPIKOM, Vol. 2 No. 3 : 142 